Author running head: C. Pérez-Sayas et al.

Title running head: Diel and seasonal predation patterns

Correspondence: Tatiana Pina Desfilis, Universitat Jaume I, Departament de Ciències

Agràries i del Medi Natural, Campus del Riu Sec, 12071, Castelló de la Plana, Spain

Tel: +34 964 728041; fax: +34 964 728216; email: pina@uji.es

*Josep A. Jaques was formerly Josep A. Jacas

\title{
When do predatory mites (Phytoseiidae) attack? Understanding their diel and seasonal predation patterns
}

Consuelo Pérez-Sayas ${ }^{1}$, Ernestina Aguilar-Fenollosa ${ }^{1,2}$, Mónica A. Hurtado ${ }^{1}$, Josep A. Jaques $^{1, *}$ and Tatiana Pina ${ }^{1}$

${ }^{1}$ Universitat Jaume I (UJI), Departament de Ciències Agràries i del Medi Natural, Unitat Associada d'Entomologia Agrícola, UJI-IVIA. Avda. Vicent Sos Baynat, s/n, Campus del Riu

This is an Accepted Article that has been peer-reviewed and approved for publication in the Insect Science but has yet to undergo copy-editing and proof correction. Please cite this article as doi: 10.1111/1744-7917.12495.

This article is protected by copyright. All rights reserved. 
Sec, 12071, Castelló de la Plana, Spain and ${ }^{2}$ Torres Hnos. y Sucs. S.A.U., Departamento de Calidad. Pol. Ind. Agrícola, $n^{\circ}$ 2, 12590 Almenara (Castelló), Spain

\begin{abstract}
Predatory mites of the Phytoseiidae family are considered one of the most important groups of natural enemies used in biological control. The behavioral patterns of arthropods can differ greatly daily and seasonally; however, there is a lack of literature related to Phytoseiidae diel and seasonal predation patterns. The predatory activity of three phytoseiid species (two Tetranychidae-specialists, Phytoseiulus persimilis and Neoseiulus californicus, and one omnivore, Euseius stipulatus) that occur naturally in Spanish citrus orchards was observed under laboratory conditions in winter and summer. The temperature and photoperiod of the climatic chamber where the mites were reared did not change during the experiment. Our study demonstrates that phytoseiids can exhibit diel and seasonal predatory patterns when feeding on Tetranychus urticae (Acari: Tetranychidae). Neoseiulus californicus was revealed to be a nocturnal predator in summer but diurnal in winter. In contrast, $P$. persimilis activity was maximal during the daytime, and E. stipulatus showed no clear daily predation patterns. The predatory patterns described in this study should be taken into account when designing laboratory studies and also in field samplings, especially when applying molecular techniques to unveil trophic relationships.
\end{abstract}


Key words molecular techniques; photoperiod; phytoseiids; predation behavior; Tetranychus urticae

\section{Introduction}

Arthropod species are subject to environmental rhythms, and their behavioral patterns can differ greatly daily and seasonally (Weber et al., 2008; Saunders, 2010). Circadian rhythms of activity can allow the coexistence of species sharing the same habitat (Schoener, 1974), and in a biological control scenario, they may be key in shaping communities of pests and their natural enemies. Therefore, the identification of these patterns can allow the full exploitation of ecosystem services such as biological control. Indeed, it is known that predators in a given system exhibit different predatory activity based on spatial (microhabitat) and temporal (season, time of day) traits (Straub et al., 2008; Snyder, 2009). Searching rhythms in many arthropods seem to have evolved in response to resource competition or predation (Bell, 1990). Conclusive evidence of predation can be obtained only by direct observation of prey consumption by a predator, identification of feces or prey remains with orthodox methods such as dissection and subsequent visual gut-content identification, or the use of molecular tools specially designed to identify both prey and predator (Furlong, 2015; Pérez-Sayas et al., 2015; González-Chang et al., 2016). In all these cases, laboratory experiments or samplings do not separately evaluate day and night time activities.

Consequently, the contribution of nocturnal predation may be underrepresented due to the cryptic feeding activity patterns of nocturnal predators, which may actually play a greater role than has been recognized (Vickerman \& Sunderland, 1975; Pfannenstiel, 2008; Durham et 
al., 2009). In other words, experiments not distinctly addressing day and night periods may not show a detailed picture of predator-prey relationships.

An increasing number of studies promotes the adjustment of the field sampling time with the diel activity pattern of predators to obtain accurate estimations of their actual density and diversity. For instance, among Chelicerata, different types of diel activity patterns have been described (Jackson \& Poulsen, 1990; Kazak et al., 2004; Pekár et al., 2005). Salticidae are almost exclusively diurnal, while other predatory spider families such as Araneidae, Agelenidae, Clubionidae, Corrinnidae, Lycosidae and Miturgidae are nocturnal or exhibit periods of nocturnal activity (Costello \& Daane, 2005; Woltz \& Landis, 2014). In cursorial spiders, which are important predators of moth eggs in cotton, soybean, and corn, predation occurs mainly after dark (Pfannenstiel \& Yeargan, 2002; Pfannenstiel, 2008; Durham et al., 2009). Among the Acari, several studies have focused on the diel activity pattern and distribution on the plant of predatory mites (Phytoseiidae) (for example, Fleschner et al., 1955; Garcia-Marí et al., 1985; Magalhães et al., 2002; Onzo et al., 2003, 2010; Villanueva \& Childers, 2005). However, there is a lack of literature related to daily and seasonal predation patterns.

Predatory mites of the Phytoseiidae family are considered one of the most important groups of natural enemies used in biological control worldwide (Helle \& Sabelis, 1985). They can regulate densities of different pest species, such as phytophagous mites, thrips, and whiteflies (Helle \& Sabelis, 1985; Gerson et al., 2003; Zhang, 2003). In Spanish citrus orchards, there is a complex acarofauna population comprising two main herbivores, the Tetranychidae Tetranychus urticae Koch and Panonychus citri (McGregor), and several 
predatory mites belonging to the Phytoseiidae family (Abad-Moyano et al., 2009a; AguilarFenollosa et al., 2011a, 2011b; Jaques et al., 2015). Recently, our research group developed a multiplex PCR method for disentangling trophic relationships among these mites (PérezSayas et al., 2015). With this molecular tool, we were able to identify the two tetranychids and the six most abundant phytoseiid species in Spanish clementine orchards (AguilarFenollosa et al., 2011a, 2011b; Jaques et al., 2015) and to detect both tetranychid mite species in the predators' gut content. However, prey detection changed over time and depended on the predator-prey combination (Pérez-Sayas et al., 2015). Furthermore, corrected predation values, used to quantify the relative importance of each predator (Greenstone et al., 2014), highlighted the higher importance of the omnivorous Euseius stipulatus (Athias-Henriot) when compared with the T. urticae specialist Phytoseiulus persimilis Athias-Henriot (Pérez-Sayas et al., 2015). However, this importance was accredited due to its higher abundance in the field ( 7 times higher than that of $P$. persimilis) given that E. stipulatus was far less effective than expected as it preferred to feed on other food sources whereas $P$. persimilis specimens mostly preyed on tetranychids. Accordingly, $P$. persimilis was the most effective biological control agent in the system (Pérez-Sayas et al., 2015). However, the tetranychid specialist Neoseiulus californicus (McGregor), which is usually present in this system at densities above those of $P$. persimilis (Aguilar-Fenollosa et al., 2011b), was barely found during these field samplings, which took place mainly during the day in summer (Pérez-Sayas et al., 2015). Moreover, previous semi-field trials where $N$. californicus was released showed that this species was prone to seek refuge in citrus branches and trunks (Pina et al., 2013). The differences in prey detection over time between phytoseiid species, which is limited by the duration of the digestive process, the irregular phytoseiid 
captures during diurnal field samplings, and the existence of nocturnal predatory species among the Chelicerata led us to hypothesize that phytoseiids could exhibit different diel predation patterns that could also change with season. If these patterns were confirmed, a tuning of the samplings would be required to reveal the actual contribution of the different phytoseiid species. Therefore, the objective of this study was to determine whether phytoseiids exhibit different predation patterns based on the day and season.

\section{Materials and methods}

Mites

Tetranychus urticae individuals used as prey were originally collected in 2001 from clementine orchards located in La Plana region (Castelló, Spain). Colonies were maintained on bean plants (Phaseolus vulgaris L. [Fabaceae] cv. Chico) in a climatic chamber at $22 \pm 3$ ${ }^{\circ} \mathrm{C}, 60 \%-80 \%$ of relative humidity (RH) and a photoperiod of $16: 8$ light : dark (L : D) h. Bean plants were grown in a pesticide-free greenhouse.

Euseius stipulatus individuals used in the experiment were collected from clementine orchards in Montcada (Valencia, Spain). Neoseiulus californicus and P. persimilis individuals came from a laboratory colony initiated from specimens purchased from Koppert Biological Systems S.L. (Spical and Spidex, respectively). Neoseiulus californicus and P. persimilis were reared as described by Overmeer (1985a). Tetranychus urticae-infested bean leaves were added as food. The E. stipulatus rearing unit was slightly modified due to their different feeding requirements. This phytoseiid was reared on upside-down bean leaves, and 
Carpobrotus edulis (L.) (Aizoaceae) pollen was added twice a week as a food source, as well as all stages of T. urticae. Phytoseiid colonies were kept in climatic chambers at $25 \pm 1{ }^{\circ} \mathrm{C}$ and $80 \% \pm 5 \%$ RH. The photoperiod was set as described below.

\section{Experimental conditions}

Experiments were replicated in winter and summer to coincide with minimum and maximum day length for each season. At our location (Montcada: 39³5'18.62"N, $\left.0^{\circ} 23^{\prime} 41.68^{\prime \prime} \mathrm{W}\right)$, this coincides with a scotophase of $9 \mathrm{~h}$ and a photophase of $15 \mathrm{~h}$ in summer and vice versa in winter. The photoperiod in the climatic chamber was set at $15 \mathrm{~L}: 9 \mathrm{D}$ h to mimic summer light conditions. Lights were switched on and off to coincide with summer solstice sunrise and sunset times, respectively. These conditions were maintained throughout the experiment and throughout the year to unveil any effect of the season on predation patterns. Temperature and $\mathrm{RH}$ conditions were the same as for the culture stocks $\left(25 \pm 1{ }^{\circ} \mathrm{C}\right.$ and $80 \% \pm 5 \% \mathrm{RH})$.

Behavioral observations at different time points were performed. These were set at midnight (00:00 h solar time, meaning sundial time), midday $(12: 00 \mathrm{~h})$, winter and summer sunrise and sunset times, and one hour before and after each of the aforementioned time points. The behavioral observations were carried out in the laboratory and after dark, red LED lamps were used to minimize disturbance.

\section{Experimental design}

This article is protected by copyright. All rights reserved. 
At least 20 young gravid females were tested per phytoseiid species, time point and season. Gravid females were isolated in modified Huffaker cells (Abad-Moyano et al., 2009b) and kept with no food but with a water supply for $48 \mathrm{~h}$ in the rearing climatic chamber conditions. After the starvation period, each adult female was transferred to a new Huffaker cell provided with one T. urticae adult female. This prey stage was selected to avoid any prey-stage species-specific preference, as P. persimilis and Euseius spp. preferentially prey on eggs and larvae, respectively, and N. californicus exhibits no prey-stage preference (Blackwood et al., 2001). Each individual was tested only once.

The predatory activity of the phytoseiid was observed under a binocular microscope for up to one hour, and the observation was discontinued as soon as the predator attacked the prey. We considered an attack to be the event where the predator contacted the prey, followed by feeding (independent of the fate of the prey). The time that elapsed until the attack was measured and taken as indicative of both the antipredator behavior of the prey and the foraging success of the predator.

\section{Data analysis}

The number of mites which attacked the prey was analyzed by means of logistic regression (attacking versus not-attacking individuals), with as factors the season and time of day during which the attack was observed and their interaction (software STATGRAPHICS Centurion XVI Version 16.1.18; StatPoint Technologies, Inc., 1982-2012). When the interaction was significant, we further analyzed results using circular statistics (Fisher, 1993; Zar, 2010) with 
Oriana Software version 4 (Kovach, 2011). Circular distributions were subjected to the Rayleigh uniformity test to check whether predation activity was uniformly distributed throughout the day. In case it was not, the mean vector and its $95 \%$ confidence interval (CI) were calculated to allow comparison of temporal heterogeneity between species. For each species, the time elapsed until attack was subjected to two-way ANOVA considering season and time of day as factors.

\section{Results}

A total of 1788 phytoseiid mites were observed throughout the experiment: 595 P. persimilis (282 in winter and 313 in summer), 551 N. californicus (251 in winter and 300 in summer) and 642 E. stipulatus (314 in winter and 328 in summer). Predation activity of $P$. persimilis and $N$. californicus varied significantly with the interaction between time of day and season (logistic regression, Table 1). Both species showed clear distinctive diel predation patterns in summer but not in winter (circular statistics, Table 2, Fig. 1), as the mean time vector $95 \% \mathrm{CI}$ during this season overlapped (Table 2 and Fig. 1). In the case of E. stipulatus, the interaction between time of day and season was not significant, time of the day was bordering significance $(P=0.052)$ and season was $(P=0.002)$ (Table 1$)$. A higher number of mites engaged in attacking activities was observed during the summer.

No significant differences were observed for the time elapsed until attack between time of day, season and the interaction of these factors for E. stipulatus and $P$. persimilis $(P>0.05$ in all cases). However, for $N$. californicus, the factor time of the day was significant $(P=$ 
0.034), and a decrease in the time elapsed until attack was observed at around midnight $(10.00 \pm 3.79 \mathrm{~min}$ versus $39.42 \pm 2.02 \mathrm{~min}$ for midnight and the rest of the time points, respectively). The average time elapsed until attack was $35.39 \pm 2.01 \mathrm{~min}$ for E. stipulatus ( $=88), 37.71 \pm 2.04 \mathrm{~min}$ for $N$. californicus $(n=86)$ and $34.21 \pm 1.34 \mathrm{~min}$ for P. persimilis $(n$ $=200)$.

\section{Discussion}

Among the factors playing a role in shaping predator-prey interactions, diel (circadian) and seasonal patterns are relevant (Cloudsley-Thompson, 1970; Vickerman \& Sunderland, 1975; Penteriani et al., 2013; Ximenez-Embun et al., 2014). However, until recently, studies focusing on the reproductive biology or predatory activity of predatory mites had considered the influence of light intensity (quality) or day length (quantity, photoperiod) under simulated conditions in a particular season (Smith \& Newsom, 1970; Maeda et al., 2000; Kazak et al., 2004; Zilahi-Balogh et al., 2007). Only recently has the effect of seasonal climatic variations on the efficacy of predatory mites for thrips control in greenhouses been addressed (Hewitt et al., 2015). Our study shows that the behavioral pattern of predation changed daily and seasonally, although photoperiod and temperature in the rearing chambers remained the same during the whole experimental period, and these changes were species-specific. Thus, the pattern of predation of the Tetranychus specialist $P$. persimilis was affected by season, time of day and the interaction of these factors; that of the tetranychid specialist N. californicus was also affected by season and its interaction with time of day; and that of the omnivorous E. stipulatus by season but not by time of day. These differences should be taken into account 
when performing laboratory studies on phytoseiid species and/or when establishing the sampling time to obtain a real snapshot of mite trophic relationships, as in the case of the gut content DNA analysis (Pérez-Sayas et al., 2015). Experiments ignoring these differences may lead to biased, species-specific estimations of predation.

Among the seasonal patterns described in arthropods, including mites, one of the most studied is diapause (Morewood, 1993; Castagnoli et al., 1996; Danks, 2003). This seasonal rest is a genetically determined trait and is manifested as suppressed development or reproduction (Danks, 1987; Kroon \& Veenendaal, 1998). Primary cues for diapause induction are photoperiod and temperature (Hairston and Kearns, 1995). These factors were not modified in the rearing chambers during our study. However, the two specialist species showed a reduction in predatory activity in winter despite constant climatic conditions in the rearing chamber (Table 2). Phytoseiulus persimilis is thought to be incapable of entering diapause (Overmeer, 1985b; Morewood, 1993), as are most of the strains of N. californicus (Castagnoli et al., 1996) and E. stipulatus (Ferragut et al., 1988). Their main tetranychid prey, T. urticae, is described as exhibiting diapause in temperate regions (Takafuji, 1994; Hoy, 2011) and in some regions of the Mediterranean basin (Koveos et al., 1993). In northeastern Spain, females are active throughout the year (Martínez-Ferrer et al., 2006), but nevertheless we cannot discount a reduction in the activity of this poikilothermic species. The strict feeding habits of $P$. persimilis and the strong preference of $N$. californicus for $T$. urticae (McMurtry \& Croft, 1997; McMurtry et al., 2013) could have induced predator-prey adaptations in their feeding behavior and physiology to improve survival when prey is scarce (Ragusa \& Tsolakis, 2000). In other words, specialist predators could reduce their predation 
and oviposition rates in periods when prey is not abundant or less active (Veerman, 1992; Belozerov, 2009). These facts lead us to consider that phytoseiids could have developed an internal biological clock in sync with the periods of reduced activity of their prey. In fact, photoperiodic responses are considered to be an adaptation to seasonal changes due to their direct implication in survival and reproductive success (de Wilde, 1962; Johnsson, 2008; Belozerov, 2009; Ikeno et al., 2010).

There is either evidence for the involvement of the circadian clock in mediating photoperiodic responses in organisms ranging from fungi to mammals (Goto, 2013). In fact, T. urticae shows a mixture of circadian and apparently noncircadian features (Saunders, 2010) that could explain different daily rhythms in predators that have coevolved with this phytophagous mite. We found that predation by specialist predators was concentrated at different times depending on the species and the season, but that most avoided feeding during midday hours in summer. In predator-prey systems, light or dark preferences could influence feeding or reproduction, as these are frequently associated with the spatial distribution of food sources (e.g., adaxial or abaxial side of the leaf) (Villanueva \& Childers, 2005; Sudo \& Osakabe, 2011). Tetranychus urticae and P. citri distributions, mostly on lower and upper leaf surfaces, respectively (Tachi \& Osakabe, 2012), have been associated with their different sensitivity to UV radiation (Ohtsuka \& Osakabe, 2009; Fukaya et al., 2013; Suzuki et al., 2013; Ghazy et al., 2016). Therefore, differences in the time of day at which predation occurred could be related to the position of the preferred prey and/or their different UV sensitivity, such as $P$. persimilis being less UV sensitive than N. californicus (Tachi \& Osakabe, 2012, 2014; Ghazy et al., 2016). Accordingly, our results show that the latter 
preferentially preyed early in the morning and late in the evening in summer and winter, respectively (Table 2). The lack of effect of time of day in the predation pattern observed for E. stipulatus may be related to a higher tolerance to UV radiation than that of the other two phytoseiids studied. However, Garcia-Marí et al. (1985) found E. stipulatus preferentially on the abaxial side of the citrus leaf during the daytime. This behavior could be related to an avoidance of the lethal effects of UVB irradiation, as suggested for Amblydromalus (=Typhlodromalus) manihoti (Moraes) and Euseius fustis (Pritchard and Baker) on cassava plants (Onzo et al., 2010).

The time elapsed until the predator attacks and feeds on the prey can be taken as evidence of both the antipredator behavior of the prey and the foraging success of the predator. On the one hand, antipredator behavior is elicited when the prey perceives cues associated with predators and normally includes the avoidance of areas with predators, seeking refuge and escaping; it implies carrying costs such as a reduction in fitness and delayed development (see revision in Dias et al., 2016). On the other hand, foraging behavior comprises a group of processes by which the organisms obtain energy and nutrients and in the case of predators comprises searching, assessment, pursuit and handling (actual prey consumption) (Kramer, 2001). Despite the fact that both behaviors could change with season and time of day, the time elapsed until attack changed only for $N$. californicus.

To sum up, our study reveals that phytoseiids exhibit diel and seasonal predatory patterns. Importantly, these patterns can affect laboratory and field studies. Consequently, different testing and sampling times should be taken into account to obtain comprehensive information, especially when different species are compared. In our study, N. californicus 
was revealed to be a nocturnal predator in summer but diurnal in winter. In contrast, $P$. persimilis activity was maximal during the daytime (around midday in winter and at approximately 17:00 $\mathrm{h}$ in summer), and E. stipulatus showed no clear daily predation patterns. If these differences are neglected when planning and executing experiments, the results could lead to biased estimations of predator performance. This is especially important when designing field-sampling plans through multiple PCR approach for gut DNA detection, as prey DNA degrades rapidly in the predator gut (Pérez-Sayas et al., 2015).

\section{Acknowledgments}

This work was partially funded by the Spanish Ministry of Science and Innovation (Projects: AGL2008-05287-C04/AGR and AGL2011-30538-C03-01) and the Bancaixa Foundation-

Universitat Jaume I Research Program (P1-1A2005-03 and P1-1B2008-02). T. Pina was the recipient of a postdoctoral grant (PICD) from UJI.

\section{Disclosure}

The authors report no conflicts of interest to be declared.

\section{References}


Abad-Moyano, R., Pina, T., Dembilio, Ó., Ferragut, F. and Urbaneja, A. (2009a) Survey of natural enemies of spider mites (Acari: Tetranychidae) in citrus orchards in eastern Spain. Experimental and Applied Acarology, 47, 49-61.

Abad-Moyano, R., Pina, T., Ferragut, F. and Urbaneja, A. (2009b) Comparative life-history traits of three phytoseiid mites associated with Tetranychus urticae (Acari:

Tetranychidae) colonies in clementine orchards in eastern Spain: implications for biological control. Experimental and Applied Acarology, 47, 121-132.

Aguilar-Fenollosa, E., Ibáñez-Gual, M.V., Pascual-Ruiz, S., Hurtado, M. and Jacas, J. A. (2011a) Effect of ground-cover management on spider mites and their phytoseiid natural enemies in clementine mandarin orchards (I): Bottom-up regulation mechanisms. Biological Control, 59, 158-170.

Aguilar-Fenollosa, E., Ibáñez-Gual, M.V., Pascual-Ruiz, S., Hurtado, M. and Jacas, J.A. (2011b) Effect of ground-cover management on spider mites and their phytoseiid natural enemies in clementine mandarin orchards (II): Top-down regulation mechanisms. Biological Control, 59, 171-179.

Bell, W.J. (1990) Searching behavior patterns in insects. Annual Review of Entomology, 35, $447-467$.

Belozerov, V.N. (2009) Diapause and quiescence as two main kinds of dormancy and their significance in life cycles of mites and ticks (Chelicerata: Arachnida: Acari). Part 2. Parasitiformes. Acarina, 17, 3-32. 
Blackwood, J.S., Schausberger, P. and Croft, B.A. (2001) Prey-stage preference in generalist and specialist phytoseiid mites (Acari: Phytoseiidae) when offered Tetranychus urticae (Acari: Tetranychidae) eggs and larvae. Environmental Entomology, 30, 1103-1111.

Castagnoli, M., Liguori, M., Simoni, S., Pintucci, M., Guidi, S. and Falchini, L. (1996) Observations on diapause induction in three phytoseiid (Phytoseiidae) species. Acarology IX. Vol. 1. (eds. M. Rodger, D.J. Horn., G.R. Needham \& W.C. Welbourn), pp. 425-531. The Ohio Biological Survey, Columbus.

Cloudsley-Thompson, J.L. (1970) Recent work on the adaptive functions of circadian and seasonal rhythms in animals. Journal of Interdisciplinary Cycle Research, 1, 5-19.

Costello, M.J. and Daane, K.M. (2005) Day vs. night sampling for spiders in grape vineyards. The Journal of Arachnology, 33, 25-32.

Danks, H.V. (1987) Insect Dormancy: An Ecological Perspective. Biological Survey of Canada (Terrestrial Artropods), Ottawa.

Danks, H.V. (2003) Studying insect photoperiodism and rhythmicity: components, approaches and lessons. European Journal of Entomology, 100, 209-221.

De Wilde, J. (1962) Photoperiodism in insects and mites. Annual Review of Entomology, 7 , 1-26.

Dias, C.R., Bernardo, A.M.G., Mencalha, J., Freitas, C.W.C., Sarmento, R.A., Pallini, A. and Janssen, A. (2016) Antipredator behaviours of a spider mite in response to cues of dangerous and harmless predators. Experimental and Applied Acarology, 69, 263-276.

This article is protected by copyright. All rights reserved. 
Durham, S., Flores, A. and Comis, D. (2009) Working after hours - a nighttime view of insect predation. Agricultural Research, October, 10-11.

Ferragut, F., Costa-Comelles, J., Garcia-Marí, F., Laborda, R., Roca, D. and Marzal, C. (1988) Dinámica poblacional del fitoseido Euseius stipulatus (Athias-Henriot) y su presa Panonychus citri (McGregor) (Acari: Phytoseiidae, Tetranychidae), en los cítricos españoles. Boletín de Sanidad Vegetal. Plagas, 14, 45-54.

Fisher, N.I. (1993) Statistical Analysis of Spherical Data. Cambridge University Press, Cambridge.

Fleschner, C.A., Hall, J.C. and Ricker, D.W. (1955) Natural balance of mite pests in an avocado grove. California Avocado Society, 39, 155-162.

Fukaya, M., Uesugi, R., Ohashi, H., Sakai, Y., Sudo, M., Kasai, A., Kishimoto, H. and Osakabe, M. (2013) Tolerance to solar ultraviolet-B radiation in the citrus red mite, an upper surface user of host plant leaves. Photochemistry and Photobiology, 89, 424-431.

Furlong, M.J. (2015) Knowing your enemies: integrating molecular and ecological methods to assess the impact of arthropod predators on crop pests. Insect Science, 22, 6-19.

Garcia-Marí, F., Laborda, R., Costa-Comelles, J., Ferragut, F. and Marzal, C. (1985) Ácaros fitófagos y depredadores de nuestros cítricos Cuadernos de Fitopatología, 2, 54-63.

Gerson, U., Smiley, R.L. and Ochoa, R. (2003) Mites (Acari) for Pest Control. Blackwell Science Ltd., Oxford. 
Ghazy, N.A., Osakabe, M., Negmd, M.W., Schausberger, P., Gotoh, T. and Amano, H. (2016) Phytoseiid mites under environmental stress. Biological control, 96, 120-134.

González-Chang, M., Wratten, S.D., Lefort, M.C. and Boyer, S. (2016) Food webs and biological control. A review of molecular tools used to reveal trophic interactions in agricultural systems. Food Webs, 9, 4-11.

Goto, S.G. (2013) Roles of circadian clock genes in insect photoperiodism. Entomological Science, 16, 1-16.

Greenstone, M.H., Payton, M.E., Weber, D.C. and Simmons, A. (2014) The detectability half-life in arthropod predator-prey research: what it is, why we need it, how to measure it, and how to use it. Molecular Ecology, 23, 3799-3813.

Hairston, N.G. and Kearns, C.M. (1995) The interaction of photoperiod and temperature in diapause timing: a copepod example. Biological Bulletin, 189, 42-48.

Helle, W. and Sabelis, M.W. (eds.) (1985) Spider Mites. Their Biology, Natural Enemies and Control. World Crop Pests, Vol. 1B. Elsevier Science Publishers B.V., Amsterdam.

Hewitt, L.C., Shipp, L., Buitenhuis, R. and Scott-Dupree, C. (2015) Seasonal climatic variations influence the efficacy of predatory mites used for control of western flower thrips in greenhouse ornamental crops. Experimental and Applied Acarology, 65, 435450.

Hoy, M.A. (2011) Agricultural Acarology: Introduction to Integrated Mite Management. CRC Press (Taylor and Francis Group), Boca Raton. 
Ikeno, T., Tanaka, S.I., Numata, H. and Goto, S.G. (2010) Photoperiodic diapause under the control of circadian clock genes in an insect. BMC Biology, 8, 116.

Jackson, R.R. and Poulsen, B.A. (1990) Predatory versatility and intraspecific interactions of Supunna picta (Araneae: Clubionidae). New Zealand Journal of Zoology, 17, 169-184.

Jaques, J.A., Aguilar-Fenollosa, E., Hurtado-Ruiz, M.A. and Pina, T. (2015) Food web engineering to enhance biological control of Tetranychus urticae by phytoseiid mites (Tetranychidae: Phytoseiidae) in citrus. Prospects for Biological Control of Plant Feeding Mites and Other Harmful Organisms, Vol. 19. (eds. D. Carrillo, G.J. de Moraes \& J.E. Peña), pp. 251-269. Springer International Publishing, Switzerland.

Johnsson A. (2008) Light, circadian and circannual rhythms. Solar Radiation and Human Health (ed. E. Bjertness), pp. 57-75. The Norwegian Academy of Science and Letters, Oslo.

Kazak, C., Cone, W.W. and Wright, L.C. (2004) Influence of variable photoperiods on the feeding activity and fecundity of Galendromus occidentalis (Nesbitt) (Acari: Phytoseiidae) under laboratory conditions. Journal of Pest Science, 77, 131-135.

Kovach, W.L. (2011) Oriana-Circular Statistics for Windows, version 4. Kovach Computing Services, Pentraeth.

Koveos, D.S., Kroon, A. and Veerman, A. (1993) Geographic variation of diapause intensity in the spider mite Tetranychus urticae. Physiological Entomology, 18, 50-56. 
Kramer, D.L. (2001) Foraging behavior. Evolutionary Ecology: Concepts and Case Studies (eds. C.W. Fox, D.A. Roff \& D.J. Fairbairn), pp 232-246. Oxford University Press, New York.

Kroon, A. and Veenendaal, R. (1998) Trade-off between diapause and other life-history traits in the spider mite Tetranychus urticae. Ecological Entomology, 23, 298-304.

Maeda, T., Takabayashi, J., Yano, S. and Takafuji, A. (2000) Effects of light on the tritrophic interaction between kidney bean plants, two-spotted spider mites and predatory mites, Amblyseius womersleyi (Acari: Phytoseiidae). Experimental and Applied Acarology, 24, $415-425$.

Magalhães, S., Janssen, A., Hanna, R., and Sabelis, M.W. (2002) Flexible antipredator behaviour in herbivorous mites through vertical migration in a plant. Oecologia, 132, $143-149$.

Martínez-Ferrer, M.T., Jacas, J.A., Ripollés-Moles, J.L. and Aucejo-Romero, S. (2006) Approaches for sampling the twospotted spider mite (Acari: Tetranychidae) on clementines in Spain. Journal of Economic Entomology, 99, 1490-1499.

McMurtry, J.A. and Croft B.A. (1997) Life-styles of phytoseiid mites and their roles in biological control. Annual Review of Entomology, 42, 291-321.

McMurtry, J.A., De Moraes, G.J. and Sourassou, N.F. (2013) Revision of the lifestyles of phytoseiid mites (Acari: Phytoseiidae) and implications for biological control strategies. Systematic and Applied Acarology, 18, 297-320. 
Morewood, W.D. (1993) Diapause and cold hardiness of phytoseiid mites (Acarina: Phytoseiidae). European Journal of Entomology, 90, 3-10.

Ohtsuka, K. and Osakabe, M.H. (2009) Deleterious effects of UV-B radiation on herbivorous spider mites: they can avoid it by remaining on lower leaf surfaces. Environmental Entomology, 38, 920-929.

Onzo, A., Hanna, R., Zannou, I., Sabelis, M.W. and Yaninek, J.S. (2003) Dynamics of refuge use: diurnal, vertical migration by predatory and herbivorous mites within cassava plants. Oikos, 101, 59-69.

Onzo, A., Sabelis, M.W. and Hanna, R. (2010) Effects of ultraviolet radiation on predatory mites and the role of refuges in plant structures. Environmental Entomology, 39, 695-701.

Overmeer, W.P.J. (1985a) Rearing and handling. Spider Mites. Their biology, natural enemies and control. World Crop Pests, Vol. $1 B$ (eds. W. Helle \& M.W. Sabelis), pp. 161-170. Elsevier Science Publishers B.V., Amsterdam.

Overmeer, W.P.J. (1985b) Diapause. Spider Mites. Their biology, natural enemies and control. World Crop Pests, Vol. 1B. (eds. W. Helle \& M.W. Sabelis), pp. 95-102. Elsevier Science Publishers B.V., Amsterdam.

Pekár, S., Král, J. and Lubin, Y. (2005) Natural history and karyotype of some ant-eating zodariid spiders (Araneae, Zodariidae) from Israel. Journal of Arachnology, 33, 50-62.

Penteriani, V., Kuparinen, A., Delgado, M.M., Palomares, F., López-Bao, J.V., Fedriani, J.M., Calzada, J., Moreno, S., Villafuerte, R., Campioni, L. and Lourenço, R. (2013) 
Responses of a top and a meso predator and their prey to moon phases. Oecologia, 173, $753-766$.

Pérez-Sayas, C., Pina, T., Gómez-Martínez, M.A., Camañes, G., Ibáñez-Gual, M.V., Jaques, J.A. and Hurtado, M.A. (2015) Disentangling mite predator-prey relationships by multiplex PCR. Molecular Ecology Resources, 15, 1330-1345.

Pfannenstiel, R.S. (2008) Spider predators of lepidopteran eggs in south Texas field crops. Biological Control, 46, 202-208.

Pfannenstiel, R.S. and Yeargan, K.V. (2002) Identification and diel activity patterns of predators attacking Helicoverpa zea (Lepidoptera: Noctuidae) eggs in soybean and sweet corn. Environmental Entomology, 31, 232-241.

Pina, T., Argolo, P.S., Hurtado-Ruiz, M.A., Urbaneja, A. and Jacas, J.A. (2013) Spatiotemporal distribution and prey consumption of Phytoseiulus persimilis and Neoseiulus californicus when released in young citrus plants against Tetranychus urticae. 4th Meeting of the IOBC/WPRS Working Group "Integrated Control of Plant Feeding Mites", Paphos, Cyprus.

Ragusa, S. and Tsolakis, H. (2000) Notes on the adaptation of some phytophagous and predacious mites to various ecological parameters in the Mediterranean countries. Web Ecology, 1, 35-47.

Saunders, D.S. (2010) Controversial aspects of photoperiodism in insects and mites. Journal of Insect Physiology, 56, 1491-1502. 
Schoener, T.W. (1974) Resource partitioning in ecological communities. Science, 185, $27-$ 39.

Smith, J.C. and Newsom, L.D. (1970) Laboratory evaluation of Amblyseius fallacis as a predator of tetranychid mites. Journal of Economic Entomology, 63, 1876-1878.

Snyder, W.E. (2009) Coccinellids in diverse communities: which niche fits? Biological Control, 51, 323-335.

Straub, C.S., Finke, D.L. and Snyder, W.E. (2008) Are the conservation of natural enemy biodiversity and biological control compatible goals? Biological Control, 45, 225-237.

Sudo, M. and Osakabe, M. (2011) Do plant mites commonly prefer the underside of leaves? Experimental and Applied Acarology, 55, 25-38.

Suzuki, T., Kojima, T., Takeda, M. and Sakuma, M. (2013) Photo-orientation regulates seasonal habitat selection in the two-spotted spider mite, Tetranychus urticae. Journal of Experimental Biology, 216, 977-983.

Tachi, F. and Osakabe, M. (2012) Vulnerability and behavioral response to ultraviolet radiation in the components of a foliar mite prey-predator system. Naturwissenschaften, 99, 1031-1038.

Tachi, F. and Osakabe, M. (2014) Spectrum-specific UV egg damage and dispersal responses in the phytoseiid predatory mite Neoseiulus californicus (Acari: Phytoseiidae). Environmental Entomology, 43, 787-794. 
Takafuji, A. (1994) Variation in diapause characteristics and its consequences on population phenomena in the two-spotted spider mite, Tetranychus urticae Koch. Insect Life-cycle Polymorphism (ed. H.V. Danks), pp. 113-132. Springer, Netherlands.

Veerman, A. (1992) Diapause in phytoseiid mites: a review. Experimental and Applied Acarology, 14, 1-60.

Vickerman, G.P. and Sunderland, K.D. (1975) Arthropods in cereal crops: nocturnal activity, vertical distribution and aphid predation. Journal of Applied Ecology, 12, 755-766.

Villanueva, R.T. and Childers, C.C. (2005) Diurnal and spatial patterns of Phytoseiidae in the citrus canopy. Experimental and Applied Acarology, 35, 269-280.

Weber, D.C., Pfannenstiel, R.S. and Lundgren, J.G. (2008) Diel predation pattern assessment and exploitation of sentinel prey: new interpretations of community and individual behaviors. Proceedings of the 3rd International Symposium on Biological Control of Arthropods (eds. P.G. Mason, D.R. Gillespie \& C. Vincent), pp. 485-494. Christchurch, New Zealand.

Woltz, J.M. and Landis, D.A. (2014) Comparison of sampling methods of Aphis glycines predators across the diel cycle. Journal of Applied Entomology, 138, 475-484.

Ximenez-Embun, M.G., Zaviezo, T., and Grez, A. (2014) Seasonal, spatial and diel partitioning of Acyrthosiphon pisum (Hemiptera: Aphididae) predators and predation in alfalfa fields. Biological Control, 69, 1-7.

Zar, J.H. (2010) Biostatistical analysis. Fifth Edition. Prentice Hall, Inc., New Jersey. 
Zhang, Z.Q. (2003) Mites of Greenhouses: Identification, Biology and Control. CABI Publishing, Wallingford.

Zilahi-Balogh, G.M.G., Shipp, J.L., Cloutier, C. and Brodeur, J. (2007) Predation by Neoseiulus cucumeris on western flower thrips, and its oviposition on greenhouse cucumber under winter vs. summer conditions in a temperate climate. Biological Control, $40,160-167$.

Manuscript received October 12, 2016

Final version received May 21, 2017

Accepted May 31, 2017

Table 1 Statistical parameters of the logistic regression analysis of the attacks performed within an hour, considering season and time of day as factors. Logistic regressions fitted for all species were significant $(P<0.05)$.

\begin{tabular}{|c|c|c|c|c|c|c|c|c|c|}
\hline & \multicolumn{3}{|c|}{ Phytoseiulus persimilis } & \multicolumn{3}{|c|}{ Neoseiulus californicus } & \multicolumn{3}{|c|}{ Euseius stipulatus $^{\dagger}$} \\
\hline & $\chi^{2}$ & $\mathrm{df}$ & $P$ & $\chi^{2}$ & df & $P$ & $\chi^{2}$ & $\mathrm{df}$ & $P$ \\
\hline Season & 6.574 & 1 & 0.010 & 4.980 & 1 & 0.026 & 0.315 & 1 & 0.574 \\
\hline Time of day & 46.182 & 15 & $<0.001$ & 13.311 & 15 & 0.578 & 18.501 & 15 & 0.237 \\
\hline Interaction & 47.594 & 15 & $<0.001$ & 34.985 & 15 & 0.003 & 17.222 & 15 & 0.306 \\
\hline
\end{tabular}

This article is protected by copyright. All rights reserved. 
${ }^{\dagger}$ As the "season $\times$ time of day" interaction was not significant, the model was further depurated excluding this interaction. New $P$-values are presented in the text.

Table 2 Diel predation pattern of attacks (\# attacking individuals) by phytoseiid species and season. Mean time vector in a 24-hour time, with $P$-value, according to Rayleigh's test (the null hypothesis considers the uniformity of attacks by time of day).

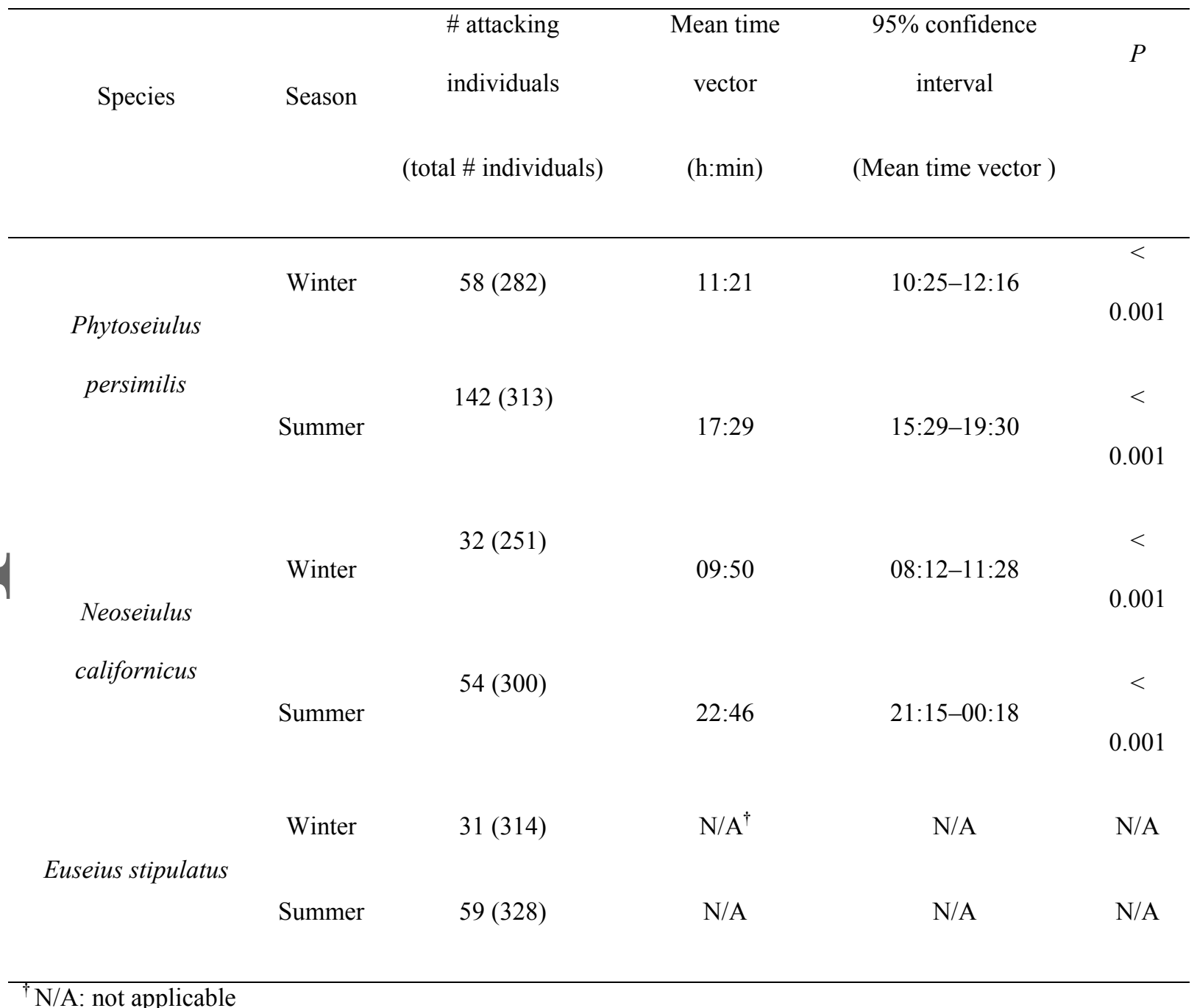




\section{Figure caption}

Fig. 1 Diel pattern of Tetranychus urticae predation by phytoseiid species (Phytoseiulus persimilis [A] and Neoseiulus californicus [B]) presented in columns according to season (winter and summer). Bars in the circular graphs represent the percentage of attacks by time of day (time point), with 00:00 h (solar time) as midnight. The line running from the center of the diagram to the outer edge and the arc represent the mean time vector and $95 \%$ confidence interval, respectively. 


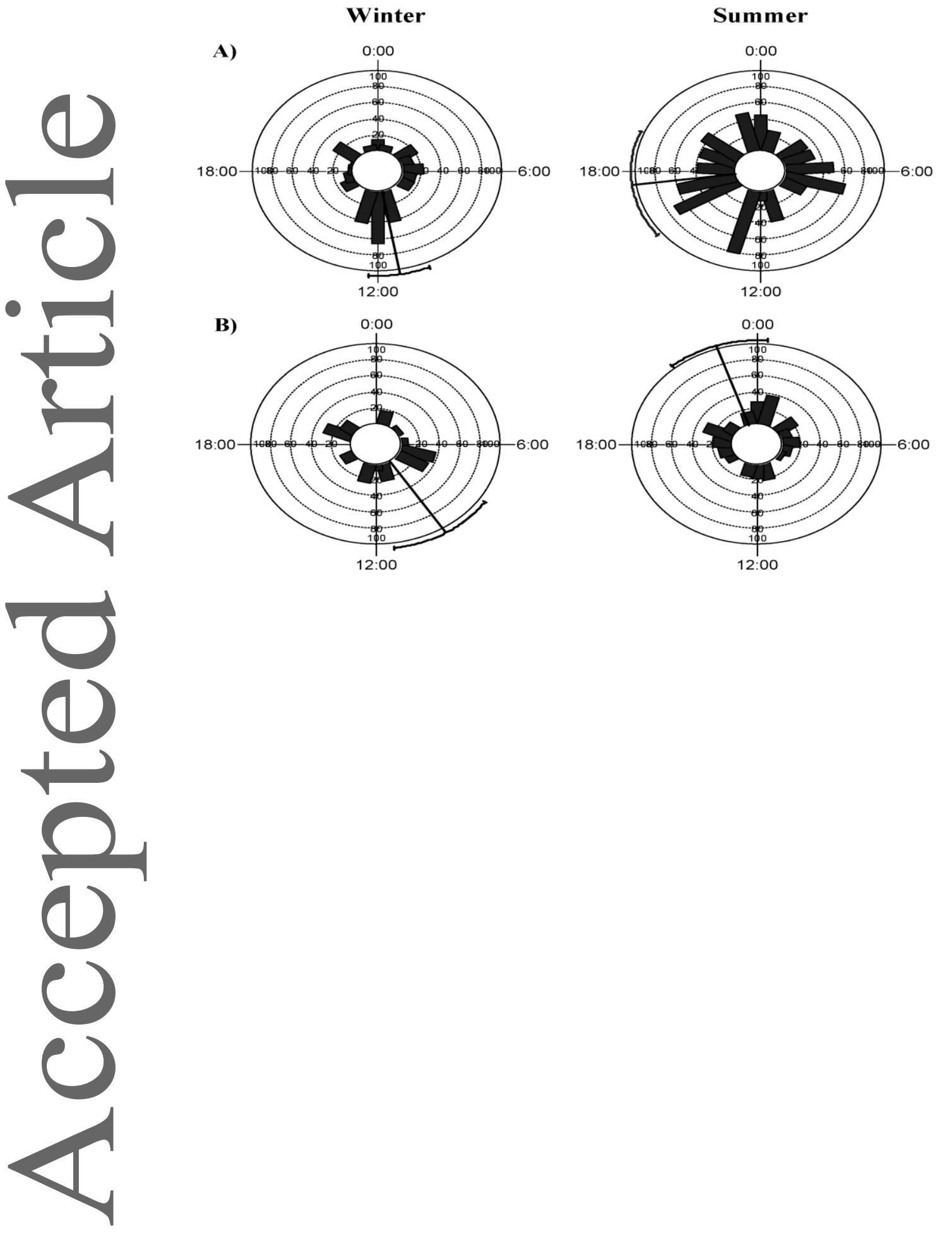

This article is protected by copyright. All rights reserved. 